\title{
Nonsendromik İşitme Kayıplı Olgularda GJB2 Mutasyon Dağılımı
}

\section{GJB2 Mutation Distribution in Cases with Nonsyndromic Hearing Loss}

\author{
Tahir Atik $^{1 *}$, Bilçağ Akgün² ${ }^{2}$ Esra Işık ${ }^{1}$, Ferda Özkınay ${ }^{1}$ \\ ${ }^{1}$ Ege Üniversitesi Tıp Fakültesi, Çocuk Sağlığı ve Hastalıkları Anabilim Dalı, Çocuk Genetik Bilim Dalı, İzmir \\ Türkiye \\ ${ }^{2}$ İzmir Ekonomi Üniversitesi Tıp Fakültesi, Tıbbi Genetik Anabilim Dalı, İzmir, Türkiye \\ e-mail: tahiratik@yahoo.com, bilcagakgun@gmail.com, esrabadak36@gmail.com, ferdafo@yahoo.com \\ ORCID: 0000-0002-1142-3872 \\ ORCID: 0000-0002-5220-5652 \\ ORCID: 0000-0003-0657-2408 \\ ORCID: 0000-0001-7542-7787 \\ *Sorumlu yazar/ Corresponding Author: Tahir Atik \\ Gönderim Tarihi / Received: 05.03.2020 \\ Kabul Tarihi / Accepted: 07.06.2020 \\ DOI: $10.34087 /$ cbusbed.698933
}

\begin{abstract}
$\ddot{O} \mathbf{z}$
Giriş ve Amaç: İşitme kaybı, popülasyonda 1/500-1000 sıklıkta rastlanan en sık görülen duyu kusurudur. Herediter işitme kayıplarının yaklaşık \%25'i sendromiktir. Nonsendromik olan kısımda ise kalıtım pateni \%80 otozomal resesif, geri kalan \%20 otozomal dominant şeklindedir. Otozomal resesif nonsendromik işitme kaybı (NSI) olgularının \%2040'ında, bir “sık1 bağlantı" proteini olan Connexin 26'y1 (Cx26) kodlayan GJB2 genindeki mutasyonlar tablodan sorumlu olarak tespit edilmektedir.

Bu çalışmada, otozomal resesif NSI şüphesiyle, 2012-2019 yılları arasında GJB2 moleküler analizi yapılan 146 olgunun sonuçları geriye dönük olarak incelenerek, GJB2 mutasyon spektrumunun belirlenmesi amaçlanmıştır.

Gereç ve Yöntemler: İşitme kaybı şikayeti ile başvuran 146 olgunun GJB2 geninin ekzonik ve ekzon-intron yapışma bölgeleri Sanger dizi analizi yöntemi ile dizilenmiştir.

Bulgular: 35 olguda GJB2 geninde homozigot ya da birleşik heterozigot mutasyon saptanmıştır. En sık saptanan mutasyon 2. ekzonda yer alan c.35delG değişikliğidir. Saptanan diğer mutasyonlar ise; c.299_300delAT, c.551G $>$ C, c.334_335delAA, c.109 G>A, c.358_360delGAG, c.71G>A şeklindedir.

Sonuç: Nonsendromik işitme kaybının etiyolojisinde en sık olarak GJB2 geni mutasyonları saptanmaktadır ve bu genin dizi analizi tanı algoritmasında ilk sırada yer almaktadır. Ayrıca çalışmamız sonucunda, nonsendromik herediter işitme kaybı ile ilişsili GJB2 genindeki saptanılan mutasyonlar paylaşılarak ülkemizdeki mutasyon spektrumunun incelenmesine katkıda bulunulmuştur.
\end{abstract}

Anahtar kelimeler: Connexin 26, GJB2, İșitme kaybı, Nonsendromik

\begin{abstract}
Objective: Hearing loss is the most common sensory defect with a frequency of $1 / 500-1000$ in the population. Approximately $25 \%$ of hereditary hearing losses are syndromic. In the non-syndromic type, the inheritance pattern is $80 \%$ autosomal recessive and the remaining $20 \%$ is autosomal dominant. In 20-40\% of cases of autosomal recessive nonsyndromic hearing loss (NSI), mutations in the GJB2 gene that encoding Connexin 26 (Cx26), a "tight junction" protein, are thought to be responsible for NSI. In this study, it was aimed to determine the GJB2 mutation spectrum by retrospectively examining the results of 146 cases whose GJB2 molecular analysis was performed between 2012 and 2019 with the suspicion of having autosomal recessive NSI.
\end{abstract}

Materials and Methods: The exonic and exon-intron splicing regions of the GJB2 gene of 146 patients who presented with the complaint of hearing loss were sequenced by the Sanger sequence analysis method. 
Results: Homozygous or combined heterozygous mutations in the GJB2 gene were found in 35 cases. The most common mutation is the c.35delG change in exon 2. The other mutations detected are; c.299_300delAT, c.551G>C, c.334_335delAA, c.109 G> A, c.358_360delGAG, c.71G>A.

Conclusion: GJB2 gene mutations are the most common cause in the etiology of nonsyndromic hearing loss, and sequence analysis of this gene takes the first place in the diagnostic algorithm. In addition, our study contributed to the examination of the mutation spectrum in our country by sharing the mutations detected in the GJB2 gene associated with nonsyndromic hereditary hearing loss.

Keywords: Connexin 26, GJB2, Hearing loss, Nonsyndromic

\section{Giris}

İşitme kaybı, sıklığı 1/500-1000 olarak karşılaşılan en sık görülen duysal defekttir. Doğumsal olabileceği gibi kazanılmış olarak da ortaya çıkabilmektedir [1]. İşitme kaybı, Kalıtsal işitme kayıplı bireylerde bir sendromun bulgusu olabileceği gibi (sendromik işitme kaybı (SI)), izole olarak da bulunabilir (nonsendromik işitme kaybı (NSI)) [2]. Çoğunluğu mendelian kalıtım özellikleri gösteren bu durumda, mutasyonlarının kalıtsal işitme kaybına sebep olduğu belirlenen çok sayıda gen bildirilmiştir. NSI olgularının yaklaşık \%80'inde resesif kalıtım paterni söz konusudur. Otozomal resesif NSI'lı olguların \%20-40'sinde, bir "sıkı bağlantı" proteini olan Connexin 26'y1 (Cx26) kodlayan GJB2 genindeki (13q11-12) mutasyonlar tablodan sorumlu olarak tespit edilmektedir $[2,3,4]$.

Cx26, özellikle iç kulakta potasyum dengesinin oluşturulmasında rol oynayan önemli bir proteindir. GJB2 geninin kodlayıcı bölgesi 681 baz çiftinden oluşmakta ve 226 aminoasitten oluşan bir proteini kodlamaktadır. Bu güne kadar, bu gen içerisinde 300'den fazla farklı mutasyon belirlenmiștir. Ancak bu mutasyonlar arasında, bazı toplumlarda sık görülen bazıları, hastalık tanı algoritmasında önemli yer tutmaktadır [5,6,7].

$\mathrm{Bu}$ çalışmada, otozomal resesif NSI şüphesiyle, 20122019 yılları arasında GJB2 moleküler analizi yapılan 146 olgunun sonuçları geriye dönük olarak incelenerek, GJB2 mutasyon spektrumunun belirlenmesi amaçlanmıştır.

\section{Materyal ve Metot}

\subsection{Hasta seçimi}

Doğuştan işitme kaybı nedeniyle genetik değerlendirme amacıyla yönlendirilen olgular arasından, yapılan muayenesi ve eşlik eden anomaliler açısından gerçekleştirilen analizler (Göz muayenesi, EKG vs.) sonucunda nonsendromik doğuştan işitme kaybı (NSDI) düşünülen, en az 3 kuşak çizilen aile ağacı analizinde otozomal resesif kalıtıma uygun özellikler gösteren (anne ve baba arasında akrabalık olması ve/veya aynı kuşakta etkilenmiş birey varlığı) ve bu nedenlerle GJB2 mutasyon analizi yapılan 146 farklı aileden 146 olgunun analiz sonuçları geriye dönük olarak değerlendirildi.

\subsection{Moleküler analizler}

Hastalara ait genomik DNA, periferik lenfositlerden standart protokol uygulanarak izole edildi. GJB2 geninin kodlayıcı bölgeleri, ekzon-intron yapışma bölgeleri ve promotor bölgeyi kapsayacak şekilde tasarlanan primerler ile (Tablo 1) PCR gerçekleştirildi. Elde edilen amplikonların büyüklükleri agaroz jel elektroforezi ile kontrol edilip uygun pürifikasyon basamaklarından sonra, ABI PRISM 3710 DNA Analiz Cihazı'nda (Applied Biosystems) ve "BigDye Terminator Cycle Sequencing V3.1 Ready Reaction Kit (Life Technologies)" kullanılarak Sanger dizi analizi uyguland1. Elde edilen varyantlar NM_004004.5 transkriptine göre isimlendirildi.

Tablo 1. GJB2 geni PCR işlemi için tasarlanan primer dizileri

\begin{tabular}{l|l}
\hline Primer ismi & Primer dizisi \\
\hline GJB2 Ekzon 1F & CCGGGAAGCTCTGAGGAC \\
GJB2 Ekzon 1R & GCAACCGCTCTGGGTCTC \\
GJB2 Ekzon 2F & TTGGTGTTTGCTCAGGAAGA \\
GJB2 Ekzon 2R & GGCCTACAGGGGTTTCAAAT \\
\hline
\end{tabular}

\section{Bulgular}

Çalışmamızda restrospektif olarak değerlendirilen 146 olgunun yaş ortalaması 29 olarak saptand. Bu olguların 91'i erkek (\%62) ve 55'i ise kadın (\%38) cinsiyetteydi. Otozomal resesif NSDI düşünülerek GJB2 gen dizi analizi gerçekleştirilen 146 olgunun 35'inde (\%24) bu gende sorumlu etiyoloji tespit edildi. 31'inde (\%86) homozigot, 4'ünde (\%14) birleşik heterozigot mutasyon saptand1. Toplam 7 farklı mutasyon tespit edilirken, bulunan mutasyonlardan hepsi daha önce tanımlanmıştı. c.35delG mutasyonu en sık saptanan değişiklik olup allel frekans1 \%21 (62/292) olarak belirlendi. Bu mutasyon saptanan olguların \%83'ünde homozigot olarak belirlendi. 4 olguda c.35delG mutasyonuna birleşik heterozigot olarak saptand1. Hastalarda tespit edilen GJB2 gen mutasyon spektrumu Tablo 2'de gösterilmiştir.

Tablo 2. Saptanan GJB2 gen mutasyonları ve olgu sayılar1

\begin{tabular}{|c|c|}
\hline Genotip & $\begin{array}{c}\text { Olgu } \\
\text { sayisi }\end{array}$ \\
\hline c. $35 \mathrm{de} 1 \mathrm{G}+$ c. $35 \mathrm{de} 1 \mathrm{G}$ & 29 \\
\hline c.299_300delAT + c.299_300delAT & 1 \\
\hline c. $551 \mathrm{G}>\mathrm{C}+$ c. $.551 \mathrm{G}>\mathrm{C}$ & 1 \\
\hline c. $35 \mathrm{de} 1 \mathrm{G}+$ c. $109 \mathrm{G}>\mathrm{A}$ & 1 \\
\hline c. $35 \mathrm{de} 1 \mathrm{G}+$ c. $358 \_360 \mathrm{de} 1 \mathrm{GAG}$ & 1 \\
\hline c. $35 \mathrm{de} 1 \mathrm{G}+$ c.334_335de1AA & 1 \\
\hline c. $35 \mathrm{de} 1 \mathrm{G}+$ c. $.71 \mathrm{G}>\mathrm{A}$ & 1 \\
\hline
\end{tabular}




\section{Tartışma}

Nonsendromik kalıtsal işitme kaybının moleküler analizinde, GJB2 geninin dizi analizi ilk basamak test olmalıdır. Connexin mutasyon veri tabanında (http://davinci.crg.es/deafness/) GJB2 geninde bugüne kadar belirlenmiş 200'den fazla farklı mutasyon bildirilmiştir.

$\mathrm{Bu}$ çalışmada, otozomal resesif NSDI nedeniyle analiz edilmiş ve ilk basamak test olarak gerçekleştirilen GJB2 gen dizi analizinde hastalığa sebep olan moleküler etiyolojinin belirlendiği 187 farklı olgu değerlendirilerek, saptanan GJB2 mutasyon spektrumu sunulmaktadır. Türkiye'de daha önce yapılan çalışmalar, diğer toplumlarla benzer şekilde, otozomal resesif NSDI olgularında GJB2 gen mutasyonlarının en sik olarak belirlendiğini göstermektedir.[3], [8] Burada sunulan araştırmada, benzer şekilde, analiz edilen 187 farklı NSDI olgusunun \%19'unda GJB2 etiyolojiden sorumlu bulunmuştur. Uyguner ve arkadaşlarının ülkemizde yaptığı bir çalışmada, işitme kayıplı olguların \%31,7'sinde GJB2 geninde mutasyon tespit edilmiştir.[8] Yine ülkemizde Atik ve arkadaşları tarafından gerçekleştirilen bir diğer çalışmada ise bu oran $\% 24.1$ olarak saptanmıştır[3]. Bizim çalışmamızda ise NSDI olgularında GJB2 geninde mutasyon saptama oranı \%24 olarak tespit edilmiştir ve geçmiş çalışmalardaki verilerle uyumlu olduğu görülmüştür.

GJB2 genindeki c.35delG mutasyonu beyaz irkta en s1k saptanan mutasyon olarak daha önce farklı çalışmalarda bildirilmiştir [9,10,11]. Atik ve arkadaşları tarafindan yapılan çalışmada GJB2 mutasyonları olan hastalarda c.35delG mutasyonunun allel frekans1 \% 78.5 olarak saptanmıştır.[3] Çalışmamızda, en yüksek oranda c.35delG mutasyonu saptanmış olup, bu oran \%88,6 $(62 / 70)$ olarak tespit edilmiştir ve benzer şekilde yüksektir. Tekin ve arkadaşları tarafindan yapılmış olan bir başka çalışmada, işitme kayıplı olguların olguların $\% 15$ 'inde homozigot c. $35 \mathrm{delG}$ mutasyonu mutasyonu saptanmıştır[12]. Bizim çalışmamızda ise bu oran, \%19,8 olarak tespit edilmiştir ve Tekin ve arkadaşlarının çalışmasının verileriyle korele olduğu görülmüştür. Literatürde, c.35delG mutasyonunu sirasiyla c.167delT ve c.235delC mutasyonları takip etmektedir. c.167delT mutasyonu Askenazi Yahudilerinde, c.235delC mutasyonu ise Japonya ve Çin toplumlarında yüksek oranda görülmektedir $[13,14,15,16]$. Çalışmamızda bu iki mutasyona da rastlanılmamıştır.

Çalışmamızda 4 farklı olguda bileşik heterozigot mutasyon saptanmıştır. Bu 4 olgunun da bir allellerindeki değişiklik c.35delG mutasyonu iken diğer allellerindeki mutasyonlar birbirinden farklıdır (c109G $>$ A, c.358_360delGAG, c.334_335delAA, c.71G>A). Bu dört farklı mutasyon daha önce literatürde bildirilmiştir. Merkezimize GJB2 dizi analizi amacıyla yönlendirilen işitme kayıplı her olgunun aile ağacı bilgilerine ulaşamadığımız için, işitme kaybının etiyolojisinde düşünülecek kalıtım modelinin net olarak belirlenememesi çalışmamızın kısıtlılıkları arasındadır. Ancak ülkemizde akraba evliliği, aynı köy ve yakın köy evlilikleri sık olduğundan tüm işitme kayıplı olgularda ilk test olarak GJB2 dizi analizi yapılmaktadır. Aynı zamanda çalışmamıza yalnızca nonsendromik işitme kaybı olguları dahil edilmesine rağmen, Usher sendromu gibi yaşa bağlı penetrans gösteren hastalıklar öngörülemeyeceğinden sendromik işitme kayıpları tamamen dışlanamamaktadır.

\section{Sonuç}

Sonuç olarak, nonsendromik işitme kaybının etiyolojisinde en s1k olarak GJB2 geni mutasyonları saptanmaktadir ve bu genin dizi analizi tanı algoritmasında ilk sırada yer almaktadır.

\section{Referanslar}

1.Morton, C.C, Nance, W.E, Newborn hearing screening--a silent revolution, The New England Journal of Medicine, 2006, 354(20), 2151-64.

2.Bayazıt, Y.A, Cable, B.B, ve ark., GJB2 gene mutations causing familial hereditary deafness in Turkey, International Journal of Pediatric Otorhinolaryngology, 2003, 67(12), 1331-1335.

3. Atik, T, Onay, H, ve ark., Comprehensive analysis of deafness genes in families with autosomal recessive nonsyndromic hearing loss, PLoS One, 2015, 10(11), e0142154.

4. Atik, T, Bademci, G, ve ark., Whole-exome sequencing and its impact in hereditary hearing loss, Genetics Research, 2015, 97.

5. Frei, K, Szuhai, K, ve ark., Connexin 26 mutations in cases of sensorineural deafness in eastern Austria, European Journal of Human Genetics, 2002, 10(7), 427-32.

6. Rabionet, R, Gasparini, P, ve ark., Molecular genetics of hearing impairment due to mutations in gap junction genes encoding beta connexins, Human Mutation, 2000, 16(3), 190-202.

7.Kiang, D.T, Jin, N, ve ark., Upstream genomic sequence of the human connexin 26 gene, Gene, 1997, 199(1-2), 165-71.

8. Uyguner, O, Emiroglu, M, ve ark., Frequencies of gap- and tightjunction mutations in Turkish families with autosomal-recessive nonsyndromic hearing loss, Clinical Genetics, 2003, 64(1), 65-69.

9.Lench, N.J, Markham, A.F, ve ark., A Moroccan family with autosomal recessive sensorineural hearing loss caused by a mutation in the gap junction protein gene connexin 26 (GJB2), Journal of Medical Genetics, 1998.

10. Estivill, X, Fortina, $P$, ve ark., Connexin-26 mutations in sporadic and inherited sensorineural deafness, Lancet, 1998.

11. Gasparini, P, Rabionet, R, ve ark., High carrier frequency of the 35 delG deafness mutation in European populations. Genetic Analysis Consortium of GJB2 35delG, European Journal of Human Genetics, 2000.

12. Tekin, M, Boğoclu, G, ve ark., Evidence for single origins of $35 \mathrm{delG}$ and delE120 mutations in the GJB2 gene in Anatolia, Clinical Genetics, 2005.

13. Fuse, Y, Doi, K, ve ark., Three novel connexin26 gene mutations in autosomal recessive nonsyndromic deafness, Neuroreport, 1999.

14. Kudo, T, Ikeda, K, ve ark., Novel mutations in the connexin 26 gene (GJB2) responsible for childhood deafness in the Japanese population, American Journal of Medical Genetics, 2000.

15. Abe, S, Usami, S.I, ve ark., Prevalent connexin 26 gene (GJB2) mutations in Japanese, Journal of Medical Genetics, 2000.

16. Morell, R.J, Kim, H.J, ve ark., Mutations in the connexin 26 gene (GJB2) among Ashkenazi jews with nonsyndromic recessive deafness, The New England Journal of Medicine, 1998.

http://edergi.cbu.edu.tr/ojs/index.php/cbusbed isimli yazarın CBU-SBED başlıklı eseri bu Creative Commons Alıntı-Gayriticari4.0 Uluslararası Lisansı ile lisanslanmıştır.

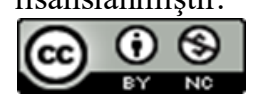

